\title{
Unlocking The Meaning Of Cultural Disclosure In Courting Language
}

\author{
Dakia N. DjoU, Fakultas Sastra dan Budaya, Universitas Negeri Gorontalo, dakiadjou@ung.ac.id \\ Asna Ntelu \\ Fakultas Sastra dan Budaya, Universitas Negeri Gorontalo, asna.ntelu@ung.ac.id \\ Ellyana Hinta, Fakultas Sastra dan Budaya, Universitas Negeri Gorontalo, ellyana.hinta@ung.ac.id \\ Mira Mirnawati, Fakultas Sastra dan Budaya, Universitas Negeri Gorontalo, miramirnawati@ung.ac.id
}

\begin{abstract}
Currently, the young generation in Gorontalo has difficulty interpreting the form of language in the Gorontalo customary proposal dialogue. It is not surprising that at this time they are unable to play an active role in traditional ritual events. The dialogue on proposal is limited only to parents who have professions and expertise on the motolobalango "peminangan" event such as traditional stakeholders. This research focuses on the meanings behind the cultural expressions in the adat marriage of Gorontalo. This study aims to describe the meaning behind the cultural expressions in the Gorontalo customary marriage. The approaches used in this research are sociolinguistic and pragmatic approaches. The two approaches above are used trianggulatively (simultaneously). The data source in this research is the transcription of the conversation or dialogue of the traditional stakeholders during the marriage ceremony. Data collection was carried out through two methods, namely: (a) observation method or observation method carried out with basic tapping techniques. In this research, it is evident that through the use of old words, figures of speech, and parables, the atmosphere is more familiar, polite, and more beautiful. Familiarity, politeness and beauty reflect refinement in language or speech.
\end{abstract}

Keywords: meaning, cultural expression, marriage speech

$\begin{array}{lll}\text { Received: 07.12.2020 } & \text { Accepted: 20.01.2021 } & \text { Published: 02.02.2021 }\end{array}$

\section{INTRODUCTION}

It is admitted that the average young generation now does not know the language used at cultural ritual events. This happened as a result of acculturation from outside which brought the Gorontalo language as a cultural medium in danger of extinction. The acculturation of external culture will become an external socio-cultural factor that influences and shapes the cultural ecology that currently occurs in certain ethnicities (Hisa, Agustinus Mahuse, and I Wayan Arka, 2017: 190).

In Gorontalo society, a man who wants to marry a woman must go through several stages of activities to get to the wedding ceremony, one of which is the marriage ceremony. This nomination activity involves people who work in the cultural field of 'penginangan' tolobalango, especially because of the ability to have a verbal dialogue at the event. The marriage dialogue in Gorontalo society radiates thoughts, life, and living traditions. The speaker in the proposal dialogue begins by describing ideas and ways of thinking in a clear, logical, and as satisfying way as possible (Liliweri, 2003: 154). What is expected in this proposal dialogue is an understanding and agreement between the two parties. In addition, the engagement dialogue can give the same meaning to communication messages.

Communication in a candidate dialogue is effective when both parties manage to minimize misunderstandings as possible. Rogers (through Liliweri, 2003: 228) says that effective intercultural communication occurs when a mutual understanding occurs. What is meant by mutual understanding is the state of a person being able to predict how other people give meaning to the message sent and encode the message received.

The dialogue activity in the proposal can be seen as a cultural communication process. As a process, communication can certainly be built by five elements that depend on each other (Mulyana, 2001: 63). First, the source or what is often called the sender (sender), encoder, communicator (communicator), speaker (speaker). The source or the communicator is the party who initiates the communication, meaning that he is the one who initiates the delivery of a certain message to another party called the communicant. Furthermore, the other party will respond so that there is an interaction between the sender of the message and the recipient of the message. In the process of winning dialogue, there is an exchange of positions between the two interacting parties. That is, there is an exchange of roles, in this case the sender of the message at certain times changes to the recipient of the message and 
vice versa. The exchange of roles continues until the interaction ends. In essence, the process of verbal communication is an interactive, transactional and dynamic process. Interactive communication is communication carried out by communicators and communicants in two directions or reciprocally.

Second, the message is what the source communicates to the recipient. This message is a set of verbal or nonverbal symbols that represent the feelings, values, ideas, or intent of the source. A verbal symbol is something that is used to represent a specific purpose, for example in spoken or written verbal words. Nonverbal symbols are those that are exhibited through the movements of the body or limbs.

Third, the channel or media, namely the means or vehicle used by the source to convey the message to the recipient. In communication events, there are many channels that we can use, but among the many there is one that stands out the most in the event, namely the verbal channel (language). Verbal language is the primary means of expressing our thoughts, feelings and intentions. Verbal language uses words that represent various aspects of our individual reality.

Fourth, the receiver (receiver), often also called the target or destination, back encoders or audiences who listen. In communication science, the receiver is also called the communicant. Of course, in the communication process, both the communicator and the communicant are expected to have full attention to respond and translate the message being transferred. The purpose of communication will be achieved when the communicant accepts or understands the meaning of the message from the communicator.

Fifth, effect, which is what happens to the recipient after he receives the message. In interacting, everyone communicates messages with the hope that the goals and functions of communication can be achieved. In such a process, we generally want feedback reactions, which are known as feedback. This feedback is the feedback from the communicant to the communicator for the messages that have been conveyed. Without feedback, communicators and communicants cannot understand the ideas, thoughts and feelings contained in the message.

Similar to the communication process in general, reciprocal interaction in the wedding ceremony in Gorontalo has the criteria as described above. However, the uniqueness contained in this process is the existence of verbal expressions that require deep interpretation for the two interacting parties to make their meaning clear. In this case, the two spokesmen in their respective applications use figurative forms as a means to convey the intentions and contents of the heart. These expressions have become a tradition for the people of Gorontalo which have been preserved for a long time. However, it is very concerning because many generations living today do not understand the expressions in the proposal dialogue.

It is undeniable that the people of Gorontalo, as one of the ethnic groups in Indonesia, have a way of speaking that describes the characteristics and norms that the Gorontalo people value. These characteristics and norms are actualized in regional cultural and customary events using the Gorontalo language (hereinafter abbreviated as BG) as the medium. In general, the variety of languages at traditional events is much different from the variety of BG used in daily interactions. BG at the ceremony, generally use old words so that it is difficult for the current generation to interpret them. In addition, the sentence structure is long, has traditional nuances, has lyrics and uses a choice of words that tend to have a classical meaning. The meaning is also full of local cultural or customary content (Jufrizal, 2004: 166).

The spoken language at the ceremony in Gorontalo is a type of spoken speech that has oral characteristics in BG. The oral characteristics of a language are now becoming people's attention. Teeuw (1991: 1) states that oral literacy and literacy in modern science are increasingly attracting attention, both in terms of linguistics and literature, as well as in terms of anthropology and psychology, as well as from media experts.

Thus, to get a clear picture of the meaning of BG at the ceremony, it is necessary to study the cultural expressions spoken by the customary leaders as speakers at the wedding ceremony.

This research focuses on the meaning behind the cultural expressions of the marriage according to the Gorontalo custom. The meaning of these expressions can be viewed from various types of context, namely: (1) cultural context; (2) social context; (3) religious context; (4) aesthetic context; (5) ethical context.

The issue of meaning that is raised becomes the focus of this study because it remembers the importance of cultural expressions in the sociocultural life of Gorontalo people. The meaning of cultural expressions is very important to worry about the younger generation who will lose their sources, so that from now on, efforts are being made to preserve them. At a minimum, cultural-language documentation is available when they will need it. 


\section{METHOD}

The approaches used in this research are sociolinguistic and pragmatic approaches. The sociolinguistic approach places the position of language in relation to its use in society (Suwito, 1983: 2). The pragmatic approach was used to analyze the data in this study. There are two things that must be considered in implementing this pragmatic approach, namely, speech events and speech acts. If we refer to Hudson's opinion (1980: 106) that speech events are more focused on the purpose of events in speech (Suryadi, 1983, Yanti, 2001, Chaniago, 2001, and Baihaqi, 2007). The speech act focuses more on the meaning of the act (act) in a speech.

The two approaches above are used trianggulatively (simultaneously). This means that the sociolinguistic approach will not be used alone but accompanied by a pragmatic approach. The pragmatic approach is used to analyze the meaning behind expressions based on context (Tuloli, 2000: 119).

The data source in this research is the transcription of the conversation or dialogue of the traditional stakeholders during the marriage ceremony. Data collection was carried out through two methods, namely: (a) observation method or observation method carried out with basic tapping techniques. The tapping technique is carried out through recording and recording; (b) interview method or proficient method with basic fishing rod techniques (Mahsun, 2005: 90-94; Sudaryanto, 1993: 133$140)$.

\section{RESULTS AND DISCUSSION}

\section{Result}

The indigenous variety of Gorontalo language has cultural meaning. The speech interpreted in this study is in the form of:

1. Wonu ito tahu-tahu iitani, de amiyaatia ta me'iyango mai. "If you keep the diamonds, we'll form the rings later."

2. Wonu ito o polohungo de amiyaatia ta lalaaita mai he momuhuto. "If you look after ornamental flowers, let us come to water them".

3. Wonu ito bia-biahe buurungi, de amiyaatia ta hemopo'a mai. "If you raise birds, let us take care of them or give them food '.

In traditional language there are cultural expressions that we can interpret as the hope of togetherness from the sender of the message to the recipient of the message. The phrases are as follows.

Ito wolo mongowutatonto mealo keluarga helu-helumo "You and your siblings or a united family". Amiyaatia 'We',

Ito wau watotia sama-sama utolia

'You and I are both spokespersons',

Mongobubato ma hi haadiria

'The invitees (relatives) have attended',

Aadati lo mongotiombunto mulo

'The customs of our former ancestors'.

Human love for Allah is not only manifested through the five daily prayers, but also through speech, attitudes and behavior, as well as actions, all of which are manifested through social activities in society. Marriage is a social activity that expects redha and protection from Allah SWT. The spokesperson in the proposal is an ordinary human, of course, must pray and ask Allah SWT's blessing. to initiate a dialogue for this activity to run smoothly. The form of this belief is expressed in the speech below.

Assalamu alaikum wr. wbr. Bismillah hirrahmaanir rahim alhamdulillahi rabbil aalamiin wabihinastaiinu ala umuriddunya waddiin wssalatu wassalamu ala sayidina muhammadin wa ala alihi wa sahbihi ajmain amma ba'du

Syukuru wau dewo popotaluwonto mola ode kudrati lo Eya ta ohu'uwo lo aalamu mo'aa'amila, ta ima-imato mai polo'utia lo dunia wau agama tu'udu u yilomata kudurati iradatilio Eya ito ma melolotalua wolo mongowutatonto to taambati botia. Salawati wau salamu du'ola olo Nabiinto Nabi Muhammad saw. Tanggalepata ma'o de sahaabatilio wolo ongongaala'a lodudu'a olio wolo toonula hihilingalio du'aanto ito helu-heluma to bilulo'a molimomota to hianga botia ta laita tima-timanga to saree'atilio.

For some Gorontalo people, especially the customary stakeholders, they convey this beautiful feeling through the diaologue in the proposal when they act as spokespersons for the activity. There the spokesperson has the freedom to add, subtract and simplify words in the dialogue. This is done, in addition to the intention of playing with words to make them sound more beautiful and attractive, it also means that the assemblies who are present at the wedding ceremony avoid feeling bored due to the use of words that are too profuse. As an example of this beauty expression we can see in the following speech. 
Ju! Alhamdulillah moduliala mola

kaulu lo ta odelo ito utolia

tanu ma meipota-potaito lo'ia

ode olamiyaatia hi haadiria

dabo to oowoluwo lo watotia utolia

bota pilopobadaria to lo'ia

tanu donggo utahata lo'u molaayilia

ode tili mohuwalia

polu-polutu'o ode wakili

lo ta ohu'uo lo lipu botia

bolo potala ma mo'otoduo

izinia ito utolia.

The speech above is beautiful because the entire sentence ends with the sound a, while other parts of the speech end with the sound o. Examples like the following.

Ju! Alhamdulillah moduliala mola kaulu lo ta odelo ito utolia tau botulo

tantuuli po'uda'a u mulo-mulo,

amiya:tia botia luntudulungowolato

debo ma molimamanga to mongodula'a mongowutato

tanu ma moposadia ma'o lo wuumbato.

'Ju! Alhamdulillah following your conversation as a guest '

'Of course the greatest appreciation'

'We are spokespersons'

'Still respect you and your brothers more'

'Roughly will be ready with all the equipment.

What is important in customary language is the content, purpose, and things implied in it relating to ethical issues or norms that have a social impact on the community or audience. This was revealed through the form of a formula expressed by the spokespersons in the proposal ceremony during their verbal interactions. The form of a formula that describes ethics in dialogue can be detailed as follows.
amiyaatia tia tuqudu utolia
donggo ilotuhata lo'u molalailia
ode ongongaala'a
to tili mantahiito mantahiiya
polu-polutu'a de halipa ilopujia

'Ju! Alhandulillah follow'

your talk spokesperson '

who is talking'

'

sporsons'

'still discussing first '

family

'Hope it will be soon'

'Allowed from sir'
'We are still only spokespersons'

'still obliged to deliberate '

'with family'

'Side-by-side'

'Especially to esteemed khalifa'

It did not escape their memories that they always humble themselves, always put their apologies first before speaking. The manifestation of this attitude is revealed through the following narrative.

wau tomuloolo dipolenggotolo

amiyatotia mulo-mulo momaqapu

wonu bolo woluwo u hilapu,

ma'apu po'o-po'oda:ta,

amiyatotia tuqudu donggo manusia biasa

donggo modaata u hi palonga olipata

amiyatia o hihile mohaarapu potuhata,
Odito olo amiyatotia

wonu bolo tala yilawadu,

tala lumadu, tala habari

meambola tala lapali,

tu'udu dia ta odelo ito

wolo mongowutatonto

ta meeyila-yilawadulo,

luma-lumadulo,

haba-habariiolo

meambola lapa-lapaliiolo,

wau dia ta tu'udu amiyatotia ta meehi yila-yilawade, hi luma-lumade, hi haba-haria
'And before starting'

'We apologize in advance'

'If something goes wrong'

'Apologize profusely'

'We are still only human'

'There's still a lot to be forgotten'

'We ask for directions'

'So do we'

'If you come to interrogate'

'Come sarcastically and ask'

'Or misspelled'

'Unworthy like you'

'With your brothers'

'Came for interrogation'

'Sarcastically here and there'

'Questioned'

'Or be said'

'And don't deserve like us'

'Who came to interrogate'

'Quipped being asked' 


\section{DISCUSSION}

\section{The meaning of narrative in terms of cultural context}

The indigenous variety of Gorontalo language has cultural meaning. The speech interpreted in this study is in the form of:

1. Wonu ito tahu-tahu iitani, de amiyaatia ta me'iyango mai. "If you keep the diamonds, we'll form the rings later."

2. Wonu ito o polohungo de amiyaatia ta lalaaita mai he momuhuto "If you look after decorative flowers, let us come to water them".

3. Wonu ito bia-biahe buurungi, de amiyaatia ta hemopo'a mai' "If you raise birds, let us take care of them or give them food".

The meaning contained in the three series of sentences above is that the girl is likened to a stored diamond, a decorative flower that grows in the yard of a house, and a pet bird in a cage. The girl, who is likened to a stored diamond, means that the diamond has not been of any use to someone if it is still intact or has not been made in the form of a ring. This means, what's the point of keeping a penny of diamonds or gold if it can't be used as jewelry. Likewise the girl who is likened to a diamond, who if she is not married is not yet beneficial to others as a spouse and life partner. A girl is like a valuable item that is guarded by her parents, therefore it is likened to a diamond which is expensive. Diamond is something that is ideal for everyone who wants to have it, so it is with a girl who is always a dream for every man.

So, the cultural expression above that reads: Wonu ito tahu-tahu iitani, de amiyaatia ta me'iyango mai "If you keep the diamonds, we will form the ring later 'in essence that this expression is a request from the male family for a girl to be married to her virgin son.

Girls are likened to polohungo "decorative flowers" that are kept in the yard, meaning that the girl is growing and blooming like flowers. Flowers, of course, have colors so that they are attractive to the eye, their smells are fragrant and captivate someone's heart to pick them, while girls are likened to birds being kept, because birds are a kind of animal that is beautiful and attractive but wild. Therefore, it must be carefully guarded so that people do not take it and do not fly. Must be looked after properly and specially. That is why, in Gorontalo there are usually girls who are secluded.

The purpose of this parable or figure of speech is to respect, honor and express affection for girls. In Gorontalo culture, girls are family members whose honor is always guarded, so as not to cause shame or ugliness in the family name. The expressions diamond, flower, and bird for girls show that in the traditional Gorontalo language such ameliorative words have a higher value than the word girl or woman who is the man's heart idol.

De'u polele mai diaalu de woluwo, de'u polele mai woluwo de diaalu, It says not even though there

is, it is said to exist even though it doesn't exist'.

These expressions are words of wisdom in response to a question that was revealed at the program mopo'opatata u pilo'otaawa 'looking for certainty' by the male family members of the female candidate's family. According to the Gorontalo culture, if someone gives an answer to a question, an expression that does not offend others is chosen. Pragmatically, this expression can be assumed that there is a kind of cooperation principle that must be carried out by the speaker and the interlocutor so that the communication process runs smoothly (Wijana, 1996: 46).

Paying attention to the above expression, the core of the answer lies in the contradictory style, namely "it is said that there is no even though it exists, it is said to exist even though it does not exist". To interpret this expression, the male delegation usually takes the last phrase of the speech for meaning. This is in accordance with the Gorontalo culture which has been in effect from the past until now. If the speech ends with the word "there", it means that the girl already has another candidate, so the conversation cannot be continued. If the speech ends with "none", it means that the girl doesn't have another candidate yet, so there is an opportunity to continue the conversation. In brief, there are two mandates contained in this expression, namely acceptance and rejection of someone's application.

The habit of Gorontalo people when accepting someone's application is not stated openly, but rather conveyed indirectly so that they are far from feeling "awkward" mobulilo. Likewise, the method of refusing an application is conveyed indirectly so that the person who is rejected the application is not offended. Cummings (2007: 16) states that an indirect rejection of an offer is considered more polite than stating openly on the offer.

In the meaning of Gorontalo ratios, the contradictory style above means: (1) emphasizing; (2) refine the mandate, and (3) respect the guest so as not to be offended. In general BG it can be said as: "ma o tilantahu" "engaged", and "diipo o tilantahu" "not engaged". However, this expression is less ethical in 
Gorontalo custom. (8) и ро'o-po'ooyo wau u oli-oliyo'o 'the silent and the moving', $u$ wuntu-wuntu wau $u$ hulo-hulo'o 'which is upheld and which occupied' ilata wau bulonggodu "lightning and thunder".

The verbal symbols above represent the type of object which is not a bride. Pragmatically, these cultural expressions are used according to the context at that time, so that in a timely manner, both the target audience and the general audience interpret the speech. The above expressions can be interpreted as follows.

- u po'o-po'ooyo wau u oli-oliyo'o 'who is silent and who moves', which means rice and a cow (lauppauk) which are needed at the ceremony of the wedding ceremony.

- $\quad \mathrm{u}$ wuntu-wuntu wau u hulo-hulo'o 'that is upheld and the one that is occupied', which means a wedding gown and aisle.

- $\quad$ ilata wau bulonggodu "lightning and thunder". This expression means tustles, shooting equipment, and a set of entertainment (ben). Tustels and shooting tools serve to immortalize weddings.

\section{The meaning of narrative in terms of social context}

In traditional language there are cultural expressions that we can interpret as the hope of togetherness from the sender of the message to the recipient of the message. The phrases are as follows.

Ito wolo mongowutatonto mealo keluarga helu-helumo

"You and your siblings or a united family".

Amiyaatia 'We',

Ito wau watotia sama-sama utolia

'You and I are both spokespersons',

Mongobubato ma hi haadiria

'The invitees (relatives) have attended',

Aadati lo mongotiombunto mulo

'The customs of our former ancestors'.

The above expressions reflect togetherness in the context of realizing the lofty ideals of the two human beings who love each other to the wedding. The beginning of everything began with deliberation from both parties, in which some conversations contained phrases like the one above. The meaning contained by these expressions is the value of togetherness which is always maintained by the spokesperson during the proposal. The togetherness referred to here is a social character that is embraced by every human being as a social being. Pragmatically, this communication adheres to the principle of cooperation that in a conversation is a guideline that needs to be considered and adhered to by speech participants so that communication can run smoothly and effectively and there is no misunderstanding (Grice, 1975: 47, Yule, 1996: 36-37, Nadar 2009: 24-25). This principle of cooperation must always underlie every conversation, if the conversation is expected to run smoothly.

For the people of Gorontalo, the concept of togetherness is always prominent and difficult to separate in daily life. This togetherness attitude can be manifested in the implementation of the wedding party in the form of helping, respecting each other, respecting each other, understanding each other, and complementing each other to achieve balance, or life harmony, all of which will produce a sense of unity and togetherness in the family environment.

The concept of togetherness is revealed through the words conveyed by the spokesperson in every movement serving the speech of the interlocutor. In certain positions, the spokesperson takes the opportunity and tries to involve all family relatives who are present in the marriage ceremony through expressions such as the following. This kind of speech appears in very high frequency in every dialogue, and this speech is also a reflection of the togetherness that Gorontalo people generally have.

Pragmatically, it can be assumed that there is a kind of cooperation principle that must be carried out by both parties so that the communication process in the wedding ceremony can run smoothly (Wijana, 1996: 46). In the science of communication according to Mulyana (2001: 4) that speech like this has a social function, namely for the purpose of pleasure, to show ties with others, to build and maintain cooperative relationships.

\section{The Meaning of Narrative From a Religious Context}

Human love for Allah is not only manifested through the five daily prayers, but also through speech, attitudes and behavior, as well as actions, all of which are manifested through social activities in society. Marriage is a social activity that expects redha and protection from Allah SWT. The spokesperson in the proposal is an ordinary human, of course, must pray and ask Allah SWT's blessing. to initiate a dialogue for this activity to run smoothly. The form of this belief is expressed in the speech below. 
Assalamu alaikum wr. wbr. Bismillah hirrahmaanir rahim alhamdulillahi rabbil aalamiin wabihinastaiinu ala umuriddunya waddiin wssalatu wassalamu ala sayidina muhammadin wa ala alihi wa sahbihi ajmain amma ba'du

Syukuru wau dewo popotaluwonto mola ode kudrati lo Eya ta ohu'uwo lo aalamu mo'aa'amila, ta ima-imato mai polo'utia lo dunia wau agama tu'udu u yilomata kudurati iradatilio Eya ito ma melolotalua wolo mongowutatonto to taambati botia. Salawati wau salamu du'ola olo Nabiinto Nabi Muhammad saw. Tanggalepata ma'o de sahaabatilio wolo ongongaala'a lodudu'a olio wolo toonula hihilingalio du'aanto ito helu-heluma to bilulo'a molimomota to hianga botia ta laita tima-timanga to saree'atilio.

Gratitude and respect we turn to Allah as the owner of nature, and who knows and oversees all kinds of contents. And it is for His Kurt and iradat that we can meet in this place. Salawat and greetings, let us assign it to our Prophet, Prophet Muhammad s.a.w. and to his family, friends, and hopefully it will come to those of us who were present in this place who are still faithfully following their syareat and sunnah.

What the spokesperson does is an expression of trust as behavior in the form of speech acts that are born as a reflection of emotions aimed at an object that is believed to have an influence on life in this world (Dharmojo, 2005: 119). The expressions carried out in the marriage have a vertical relationship, either directly or indirectly, with the Creator.

The salawat above begins with a greeting addressed to the assembly present. Greetings are one of the prayers that a person says when he meets another person. For this reason, greetings must be answered for Muslims. Then proceed with basmalah, which means "In the Name of Allah". This proves that every job must be in the name of Allah in order to receive grace from the Creator.

If we pay attention, the Gorontalo customary language used in the ceremony is mixed with Arabic. Apart from the speech shown above, there are also speeches on other situations where BG is a mixture of Arabic from the Koran by spokespersons from both parties at the same activity. The speech is as follows.

Bo odito amiyaatia ma mosyukuru ode Eeya ode Rasulu lolayidu uumuru

'Thus we will give thanks to Allah and the Messenger for having get a long life '.

"Give thanks to Allah and the Prophet" is an expression and teaching of Islam. There are many things we should be grateful for, including being grateful to meet in the event of a marriage in good health.

Insya Allah 'By Allah's permission'

The word Insya Allah comes from Arabic, statements and prayers so that we can do something with Allah's permission. Arabic words can appear in the verbal interaction of the proposal because the traditional system in Gorontalo is closely related to Islamic religious laws. This is imprinted in the expression: adat besendikan syarak, syarak bersendikan kitabullah (Quran).

\section{The meaning of narrative in terms of aesthetic context}

According to Baumgarten (Hartoko, 1984: 15) aesthetics is a branch of philosophy that deals with beauty. Aesthetics is concerned with the analysis of concepts and solutions to problems that arise when a person contemplates an object that contains aspects of beauty (Dardiri, 1986: 20). The beauty of speech can be manifested through interaction. Attempted to be made by the spokesperson in verbal interactions in marriage can create a pleasant atmosphere, an atmosphere of peace, and can also reduce tension. The creation of such an atmosphere is caused by effective communication. This means that through this communication both parties respect each other and accept the message conveyed because there is an aesthetic element in the interaction. Liliweri (2003: 46) emphasizes that in intercultural interactions, effective communication will only occur if both parties give the same meaning to the messages they are exchanging.

The exchange of messages is manifested through a series of languages that have literary characteristics as a manifestation of the beauty of a speech that appears individually in the form of creative ideas (Tambabayong, 1981: 115). To express the appearance of beauty by each individual can be done through various ways or forms of activity. Aesthetic factors are related to stylistics or language style (Junus, 1989: xix)

For some Gorontalo people, especially the customary stakeholders, they convey this beautiful feeling through the diaologue in the proposal when they act as spokespersons for the activity. There the spokesperson has the freedom to add, subtract and simplify words in the dialogue. This is done, in addition to the intention of playing with words to make them sound more beautiful and attractive, it also means that the assemblies who are present at the wedding ceremony avoid feeling bored due to the use of words that are too profuse. 
As an example of this beauty expression we can see in the following speech.

Ju! Alhamdulillah moduliala mola
kaulu lo ta odelo ito utolia
tanu ma meipota-potaito lo'ia
ode olamiyaatia hi haddiria
dabo to oowoluwo lo watotia utolia
bota pilopobadaria to lo'ia
tanu donggo utahata lo'u molaayilia
ode tili mohuwalia
polu-polutu'o ode wakili
lo ta ohu'uo lo lipu botia
bolo potala ma mo'otoduo
izinia ito utolia.

'Ju! Alhandulillah follow'

'Your talk spokesperson'

'Who is talking'

'Before us who attend'

'But we as spokespersons'

'Which is entrusted with the mandate'

'Still discussing first'

'with family'

'Especially to those who represent'

'Government of this country'

'Hope it will be soon'

'Allowed from sir'

The speech above is beautiful because the entire sentence ends with the sound a, while other parts of the speech end with the sound o. Examples like the following.

Ju! Alhamdulillah moduliala mola kaulu lo ta odelo ito utolia tau botulo

tantuuli po'uda'a u mulo-mulo,

amiya:tia botia luntudulungowolato

debo ma molimamanga to mongodula'a mongowutato

tanu ma moposadia ma'o lo wuumbato.

'Ju! Alhamdulillah following your conversation as a guest '

'Of course the greatest appreciation'

'We are spokespersons'

'Still respect you and your brothers more'

'Roughly will be ready with all the equipment.

The repetition of the same sound at the end of the line in the above formulas makes the audience interested in the speech, because it contains an aesthetic element. Pradopo (1987: 22) says that in poetry sound is aesthetic, it is an element of poetry to get beauty and expressive power. Besides the decoration in poetry, the sound also has an even more important task, namely to deepen speech, create feelings, and create clear imagery, create a special atmosphere, and so on. The same thing is also expressed by Luxemburg (1989: 91) that the repetition of sounds is an important means of composing the language of poetry. The impact that can be obtained by repetition is the suggestion of sound, motion, atmosphere, relationship of meaning, and expressiveness, and this is used by poets in various ways. Repetition of vowels is called asonance, consonant repetition is called alliteration. In addition, the parallelism language style, which has been previously described is an aesthetic element. Metaphors related to girls, namely paramata, canary flowers, polohungo, and others, show the speaker's skill in creating the beauty of associative meaning. Beautiful girl, associated, likened, or adorned like a gem, diamond, or a fragrant and attractive flower. All that apart from having to do with the formulaic system, is also an aesthetic element. Aesthetic values are not only figurative, but also moral values, courtesy, regular speech and directed, controlled movements. In the tuja'i that has been previously stated, these things have been described, both in dialogical, descriptive, and directional tuja'i.

In the Gorontalo language, the customary variety includes repetition of sounds, parallelism, metaphor, as a sign of aesthetic elements in the speech, which are used by customary stakeholders at the time of appearance to deepen the meaning and sense of beauty in the expression.

\section{Meaning of Narrative Viewed from an Ethical Context}

All of God's creatures are only human who are ethical. Ethics is more related to human good-bad deeds which are channeled through patterns of behavior and speech (cf Dharmojo, 2005: 40). For the people of Gorontalo, ethical issues are embedded in the behavior patterns of a person who in BG are known as kauli and pi'ili. Kauli is a regular and soothing speech or language. Speech that is polite, does not offend people, and is full of humility, while pi'ili is ethics or a gentle nature, likes to respect and respect others, a smiley appearance and good greetings (Tuloli et al, 2004: 53). Ethics is a custom of politeness that is adhered to by the people of Gorontalo both in speech acts and in the attitudes and behavior of a person in the wider community.

What is important in customary language is the content, purpose, and things implied in it relating to ethical issues or norms that have a social impact on the community or audience. This was revealed through the form of a formula expressed by the spokespersons in the proposal ceremony during their verbal interactions. The form of a formula that describes ethics in dialogue can be detailed as follows.
amiyaatia tia tuqudu utolia
'we are still only spokesperson' 
donggo ilotuhata lo'u molalailia

ode ongongaala'a

to tili mantahiito mantahiiya

polu-polutu'a de halipa ilopujia 'still obliged to discuss'

'with family'

'side-by-side'

'especially to the honorable khalifa'

The formula above contains a message that the spokesperson in the dialogue prioritizes ethics, norms, or customs of decency during the proposal. This means that all decisions are the result of deliberation from the families of the two parties. On that occasion, the spokesperson ethically asked the consent of the families present so that what was decided was a joint decision.

It did not escape their memories that they always humble themselves, always put their apologies first before speaking. The manifestation of this attitude is revealed through the following narrative.

wau tomuloolo dipolenggotolo 'and before starting'

amiyatotia mulo-mulo momaqapu 'we apologize in advance'

wonu bolo woluwo u hilapu, ' 'if something goes wrong'

ma'apu po'o-po'oda: $t a, \quad$ 'apologize as much as possible'

amiyatotia tuqudu donggo donggo modaata u hi palonga olipata 'human being 'we are still only human' 'still many are forgotten'

amiyatia o hihile mohaarapu potuhata, 'we ask for directions'

Odito olo amiyatotia

wonu bolo tala yilawadu,

tala lumadu, tala habari

'so do we'

meambola tala lapali,

'If you come to interrogate'

'Come sarcastically and ask'

tu'udu dia ta odelo ito

'Or misspelled'

wolo mongowutatonto

'Unworthy like you'

'With your brothers'

ta meeyila-yilawadulo,

luma-lumadulo,

haba-habariiolo

meambola lapa-lapaliiolo,

wau dia ta tu'udu amiyatotia

ta meehi yila-yilawade,

hi luma-lumade, hi haba-haria

meambola hi lapa-lapalia.

'came interrogated '

'sarcasm here and there '

'be asked '

'or say'

'and don't deserve like us'

'who came to interrogate '

'quipped being asked '

"Or be said'

All of the stories shown above illustrate the ethics of the spokespersons in dialogue at the proposal ceremony. Ethics like this have always survived in the context of Gorontalo culture which is expected to be imitated by the people of Gorontalo in general in their daily behavior. The ethical elements that appear in the tuja'i above are (1) apologies if something is wrong, or hilaf; (2) a statement of humility as a human being; (3) statements as if it is inappropriate to speak in front of a woman's family. All of this as a sign of respect, appreciation and courtesy.

\section{CONCLUSION}

Based on the results of research and discussion, it can be concluded that the culture of Gorontalo people from the past to the present when they want to marry the girl always uses words that have a class meaning during the marriage process. Classical words include iintani 'diamond', polohungo 'ornamental flower', bird 'bird', all of which are mere symbols of the girl. Likewise, there are verbal symbols in the marriage dialogue to symbolize non-bridal types of objects. The verbal symbols were chosen in order to smooth delivery and beautify the narrative. The symbols referred to are u po'o-po'ooyo wau u oli-oliyo'o 'which is stationary and that which moves', u wuntu-wuntu wau u hulo-hulo'o 'which is upheld and occupied', ilata wau bulonggodu 'lightning and thunder'.

Cultural expressions such as those mentioned above have the following intentions.

a. Iintani "diamond" is a very valuable thing in the eyes of everyone. The customary leaders chose the word diamond to represent the girl. This implies that the girl is a creature of God who needs to be honored, respected and respected because of its high value in the environment of her parents and family.

b. The phrase: u po'o-po'ooyo wau u oli-oliyo'o 'that is silent and that which moves' means a sack of rice and a cow, in addition to wedding expenses or expenses.

c. Furthermore, the expression u wuntu-wuntu wau u hulo-hulo'o 'which is upheld and which is occupied', has the meaning of a wedding and bridal attire. The emergence of figurative meanings and verbal symbols through the proposal dialogue is motivated by the context. Context is a 
parameter of an interaction in choosing the language used. Context refers to the situation or condition in which speech is spoken. In addition, context also acts as a benchmark in determining meaning. Pragmatically, these cultural expressions are used according to the context at that time, so that in a timely manner, both the target audience and the general audience interpret the speech.

\section{REFERENCES}

Baihaqi, M. Luthfi. (2007) Actions to Comedians in Television Media

Pragmatic Studies: Papers, at the 2007 National Linguistics Conference. MLI Surakarta.

Chaniago, Sam Mukhtar. (2001) Pragmatics. The Open University Publishing Center.

Cummings, Louise. (2007) Pragmatics: A Multidisciplinary Perspective. Translated by Eti Setiawati, et al. Yogyakarta: Student Library.

Dardiri, H.A. (1986) Humanities Philosophy and Logic. Jakarta: Rajawali.

Dharmojo. (2005) Symbol System in the Papua Waropen Munaba. Central Jakarta Language.

Grice, H.P. (1975). Logic and conversion, in Cole and Morgen. RadicalPragmatics. New. New York: Academic Press.

Hartoko, D. (1984) Humans and the Arts. Yogyakarta: Kanisius Foundation.

Hudson, R.A. (1980) Sociolinguistics. London: Cambridge Univesrity Prees.

Jufrizal. (2004) "The Minangkabau Language of Indigenous Variety: Towards Deep Drying Hegemony of the Indonesian Language "in the Journal of the Linguistic Society Indonesia August 2004 edition. Jakarta: Unika Atmajaya.

Junus, Umar. (1989) An Introduction to Stylistics. Kuala Lumpur: Council Languages and Libraries.

Leech, Geoffrey. (1993) Principles of Pragmatics, trans. M.D.D. Oka. Jakarta: Indonesian University.

Liliweri, Alo. (2003) Cultural Meanings in Intercultural Communication. Yogyakarta: LkiS.

Luxemburg, Jan van et al. (1989) About Literature. Translated by Achdiati Ikram. ILDEP series. Jakarta: Intermasa.

Mahsun. (2005) Language Research Methods: Stages, Strategies, Methods, and The technique. Jakarta: Fajar Interpratama Offset.

Mulyana, Deddy. (2001) Communication Science: An Introduction. Bandung: Youth Rosdakarya.

Nadar, F.X. (2009) Pragmatics and Pragmatic Research. Yogyakarta: Graha Science.

Parker, Frank. (1986) Linguistics for Non-Linguistics. London: Taylor and Francis, Ltd.

Pradopo, Rachmat Djoko. (1987) The Study of Poetry. Yogyakarta: Gadjah Mada University Press.

Pride, J.B and Janet Holmes (Eds.) (1979) Sociolinguistics. England: Penguin Books.

Sachari, Agus. (2002) Aesthetics: Meaning, Symbol, and Power. Bandung: ITB.

Subyantoro, Arief and FX. Suwarto. (2007) Social Research Methods and Techniques. Yogyakarta: Andi Offset.

Sudaryanto. (1993) Methods and Various Techniques of Language Analysis: An Introduction Research Forum for Culture Linguistically. Yogyakarta: Ambassador Discourse University Press.

Suryadi, M. (1983) Forms of Speech of Street Vendors in Semarang City. In

MLI Edition II 1993. Jakarta: Atma Jaya Unika.

Suwito. (1983) Early Introduction to Sociolinguistics: Theory and Problems. Surakarta: Henary Offset.

Tambayong, J. (1981) Basics of Dramaturgy. Bandung: Pustaka Prima

Teeuw, A. (1991) Indonesia Between Orality and Literacy. Jakarta: Library Jaya.

Tuloli, Nani. (2000) Literature Studies. Gorontalo: Nurul Jannah.

Tuloli, Nani et al. (2004) Research on Institutions and Functions in Culture Gorontalo. UPBJJ - UT Gorontalo in collaboration with BALITBANG PEDALDA Gorontalo Province.

Wijana, I. Dewa Putu. (1996) Basics of Pragmatics. Yogyakarta: Andi Yogyakarta.

Yanti, Yusrita. (2001) "Actions of Sorry Speech in Indonesian Amongst Minangkabau speakers "in the Indonesian Linguistic Society edition February 2001. Jakarta: Unika Atmajaya.

Yule, G. (1996). Pragmatics. Hong Kong: Oxford University Press. 